\title{
Development of Satisfaction with Employee Benefits - A Case Study on the Czech Republic
}

\author{
Marcela SOKOLOVÁ, Hana MOHELSKÁ \\ University of Hradec Králové, Hradec Králové, Czech Republic \\ \{marcela.sokolova, hana.mohelska\}@uhk.cz
}

\begin{abstract}
Unemployment in the Czech Republic is at its lowest since 1997. The current situation brings more problems to companies. For them the labour market represents a significant barrier to their further growth, because finding a qualified employee is becoming a bigger problem. The demand for the workforce is enjoyed by employees whose wages grow faster thanks to that. What is the situation like regarding employee benefits? The aim of this paper is to analyse the development of the costs of social benefits. The presented study also presents the level of satisfaction with the offer of employee benefits in the Czech Republic. In order to determine the level of job satisfaction, the survey (2013, 2015 and 2017) has been carried out repeatedly - the Czech version of the "Employment Satisfaction Questionnaire". The results confirm the fact that overall job satisfaction in the Czech Republic has been at a very low level for a long time. On average the employee benefits determinant has a small increase in satisfaction, although the cost of spending on them is decreasing slightly. In this area, we can see a place for businesses to fight for a skilled workforce.
\end{abstract}

Keywords: Employee Benefits, Satisfaction, Labour Cost, Czech Republic.

\section{Introduction}

Data from the labour market repeatedly shows that the unemployment rate in the Czech economy is the lowest across Europe. Unemployment in the Czech Republic is the lowest since $1997-2.6 \%$ in October 2017 [2]. The number of people without work at the 20-year minimum and the applicants has no problem finding a job. There are plenty of opportunities and the demand that companies place on the labour force leads to faster wage growth, which is a positive factor for employees.

The current situation brings further problems to employers. In addition to the above-mentioned wage pressure, which companies are still be able to absorb due to rising orders, another problem is labour shortages. It's lacking in both quantity as well as appropriate qualifications. This lack of staff is mentioned by the companies as the main barrier to their further growth. Therefore, employers must look for ways to gain enough qualified employees to allow for possible further growth. Employee benefits can be one such method of gaining a competitive advantage in the fight for skilled workforce. The aim of the paper: 
- is to analyse the development of cost for social benefits, i.e. employee benefits, in the context of the total labour costs development in the Czech Republic;

- to present the level of satisfaction with the offer of employee benefits in the Czech Republic.

\section{Analysis of Labour Cost and Employee Benefit Cost Development}

Table 1 shows the average labour costs from 2012-2016, including the amount of their components [2].

The average labour cost per employee represents the employer's cost per employee. They are the sum of direct costs (wages including reimbursements), social benefits, social costs/expenses, personnel costs/expenses and taxes. The subsidies received from the Labour Offices for public works or socially meaningful jobs are deducted. This is a value for an average of 1 employee over a certain period (a month/year). Sub-items are defined below:

\section{- Average gross wage per employee}

Average gross wage represents the proportion of wages without other personnel costs per employee.

\section{- Average personnel costs/expenses per employee}

Personnel costs include: costs/expenses for staff recruitment (excluding staff wages), costs/expenses for education and apprenticeships, costs/expenses for employees training for the occupation, costs/expenses for working clothes, uniforms and other costs/expenses on staff security (fare, rehabilitation care, etc.).

\section{- Average taxes and subsidies related to the employment of people per employee}

Taxes and subsidies are the difference between taxes (sanctions) related to the employment of people (excluding insurance and wage tax) and subsidies related to the employment of people.

\section{- Average social costs/expenses per employee}

Employer's social costs/expenses are statutory insurance payments (social, health and accident), costs/expenses to cover premium social programmes, supplementary pension schemes, wage compensation for the duration of temporary incapacity for work paid by the employer, other (contracted) paid by the employer, severance payments and other social benefits paid by the employer, contributions in the form of corporate savings or sale of shares, social security expenditure for social purposes, benefits for catering and refreshments, housing allowances, the difference between production costs and sales of own products to employees and service cars provided for private purposes. 


\section{- Social Benefits - Employee Benefits}

Social benefits include, for example, contributions in the form of corporate savings or sale of shares, social security expenditure for social purposes, benefits for catering and refreshments, housing allowances, the difference between production costs and sales of own products to employees.

Table 1. Labour costs in 2012 - 2016. [2]

\begin{tabular}{|c|c|c|c|c|c|c|c|c|c|}
\hline \multirow{3}{*}{ Year } & \multirow{3}{*}{$\begin{array}{l}\text { Labour } \\
\text { costs, } \\
\text { total }\end{array}$} & \multicolumn{8}{|c|}{ incl.: } \\
\hline & & \multicolumn{3}{|c|}{ Direct costs } & \multirow[b]{2}{*}{$\begin{array}{c}\text { Social } \\
\text { benefits }\end{array}$} & \multicolumn{2}{|c|}{$\begin{array}{l}\text { Social costs and } \\
\text { expenditures }\end{array}$} & \multirow[b]{2}{*}{$\begin{array}{c}\text { Personnel } \\
\text { expenditures }\end{array}$} & \multirow[b]{2}{*}{$\begin{array}{l}\text { Taxes and } \\
\text { subsidies }\end{array}$} \\
\hline & & wages & $\begin{array}{c}\text { payments } \\
\text { for days } \\
\text { not } \\
\text { worked }\end{array}$ & $\begin{array}{c}\text { total } \\
(\text { col. } 2+3)\end{array}$ & & $\begin{array}{c}\text { social security } \\
\text { contributions } \\
\text { statutory }\end{array}$ & other & & \\
\hline 2012 & 34774 & 22528 & 2561 & 25089 & 424 & 8538 & 465 & 317 & -59 \\
\hline 2013 & 34825 & 22417 & 2638 & 25054 & 428 & 8606 & 483 & 312 & -59 \\
\hline 2014 & 35715 & 23030 & 2673 & 25702 & 404 & 8946 & 406 & 340 & -83 \\
\hline 2015 & 36952 & 23824 & 2782 & 26606 & 412 & 9203 & 409 & 421 & -100 \\
\hline 2016 & 38257 & 24677 & 2889 & 27566 & 406 & 9506 & 446 & 422 & -89 \\
\hline
\end{tabular}

The table shows that year-on-year labour costs rise, the total increase between 2012 and 2016 was 3,483 CZK. However, the cost of social benefits/employee benefits do not follow this trend. On the contrary, there was a fall in 2014 from 428 CZK to 404 CZK.

Figure 1 shows a longer-term trend - since 1994. 


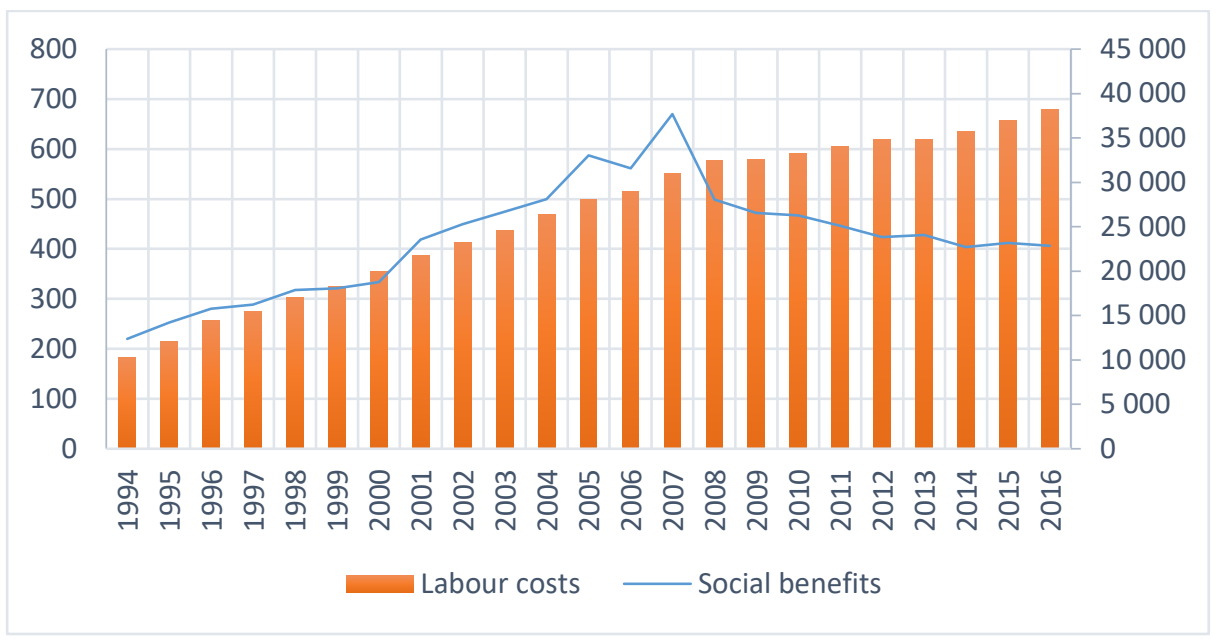

Fig. 1. Development of labour cost and social benefits in 1994 - 2016. [2]

Here, we can see that the cost of employee benefits copied labour cost growth up to 2007, in some years, the percentage increase in annual costs was even higher. In 2008 , as a result of the economic crisis, there was a significant reduction in the cost of employee benefits - from $670 \mathrm{CZK}$ to $499 \mathrm{CZK}$. In the following years, despite the subsequent rise in labour costs, the slightly decreasing trend persists.

\section{$3 \quad$ Methodology and Data}

In order to determine the level of job satisfaction, the data from the repeated surveys carried out in 2013, 2015 and in January and February 2017 were used. These surveys were carried out in the form of a questionnaire survey - the Czech version of the "Job Satisfaction Questionnaire" [6]. For the purposes of this paper, only results that measure the overall job satisfaction levels and employee benefits satisfaction levels are used.

The obtained data was collected through collaboration with university students in part-time study at the Faculty of Informatics and Management at the University of Hradec Králové.

Statistical analyses were performed using the Statistica 8 software.

Research has several limitations, but given that the Czech Republic currently has a relatively homogeneous socio-economic composition, we are convinced that our data provide results that broaden our knowledge of job satisfaction. 


\section{Satisfaction with Employee Benefits: Discussion and Results}

In total, the studies in 2013, 2015 and 2017 were attended by 1,950, or 1,547 and 1,574 respondents, 174, 77 and 98 questionnaires were excluded from the sample due to various errors and missing values.

Respondents were aged 17-74 years or 16 - 77 years in the same period in 2015 and 2017 and their average age was 36.3 years $(S D=10.80)$, i.e. 36.19 years $(S D=$ $10.70)$ and 36.36 years $(S D=11.45)$. Other selected characteristics of the respondents are given in Table 2 .

The interviewees lived mostly in the north-eastern regions of the Czech Republic the Hradec Králové and Pardubice regions and also some from Vysočina (the Czech Republic consists of 14 regions).

From the above characteristics, it's clear that the surveyed samples of respondents in all surveys are comparable.

Table 2. Selected characteristics of the surveyed sample.

\begin{tabular}{|c|c|c|c|c|c|c|}
\hline \multirow{2}{*}{ Item } & \multicolumn{2}{|c|}{2013} & \multicolumn{2}{|c|}{2015} & \multicolumn{2}{|c|}{2017} \\
\hline & Percentage & Frequency & Percentage & Frequency & Percentage & Frequency \\
\hline \multicolumn{7}{|l|}{ Gender } \\
\hline Males & 42.9 & 762 & 42.1 & 619 & 45.7 & 675 \\
\hline Females & 57.1 & 1014 & 57.9 & 851 & 54.3 & 801 \\
\hline \multicolumn{7}{|l|}{ Age } \\
\hline $\begin{array}{l}\text { Less than } \\
30\end{array}$ & 32.4 & 576 & 32.4 & 476 & 35.6 & 525 \\
\hline $30-40$ & 35.2 & 625 & 34.7 & 510 & 29.2 & 431 \\
\hline $\begin{array}{l}41 \text { and } \\
\text { above }\end{array}$ & 32.4 & 575 & 32.9 & 484 & 35.2 & 520 \\
\hline \multicolumn{7}{|c|}{ Years of experience (tenure) } \\
\hline $\begin{array}{l}\text { Less than } 5 \\
\text { years }\end{array}$ & 44.0 & 781 & 42.2 & 621 & 48.8 & 721 \\
\hline $5-10$ years & 29.5 & 524 & 29.9 & 440 & 27.5 & 401 \\
\hline $\begin{array}{l}11-15 \\
\text { years }\end{array}$ & 11.9 & 211 & 12.9 & 190 & 10.8 & 160 \\
\hline $\begin{array}{l}\text { More than } \\
15 \text { years }\end{array}$ & 14.6 & 260 & 14.9 & 219 & 13.1 & 194 \\
\hline
\end{tabular}

The results of the studies show that the total level of job satisfaction was the same in the first two surveys, i.e. 3.73, in 2017 it increased slightly to 3.76. The influence of individual determinants on total satisfaction has changed. Besides promotion, pay and 
operating conditions, other determinants that reduce overall job satisfaction levels include fringe benefits as the average level of these determinants is lower than average overall job satisfaction. On the contrary, the respondents are most satisfied with supervision, co-workers, the nature of the work and communication, whereby the average satisfaction is higher than 4.00 .

For fringe benefit determinants, there was a slight increase in satisfaction among the surveyed years from 3.42 to 3.48 , or to 3.52 in 2017 .

Table 3. The average job satisfaction scores and satisfaction with employee benefits using the respondents selected characteristics.

\begin{tabular}{|c|c|c|c|c|c|c|}
\hline Item & 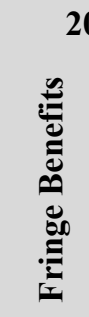 & 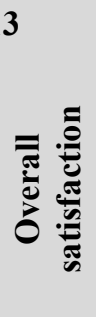 & 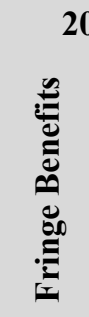 & 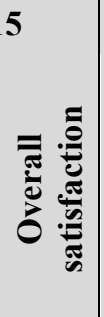 & 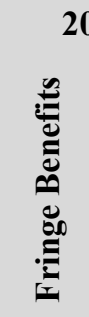 & 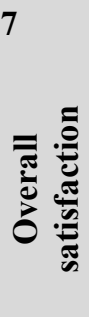 \\
\hline \multicolumn{7}{|l|}{ Gender } \\
\hline Males & 3.50 & 3.79 & 3.54 & 3.78 & 3.60 & 3.82 \\
\hline Females & 3.35 & 3.69 & 3.44 & 3.70 & 3.46 & 3.71 \\
\hline \multicolumn{7}{|l|}{ Age } \\
\hline Less than 30 & 3.43 & 3.77 & 3.53 & 3.77 & 3.54 & 3.79 \\
\hline $30-40$ & 3.46 & 3.74 & 3.48 & 3.71 & 3.64 & 3.86 \\
\hline $41+$ & 3.35 & 3.68 & 3.45 & 3.71 & 3.41 & 3.65 \\
\hline \multicolumn{7}{|c|}{ Years of experience (tenure) } \\
\hline Less than 5 years & 3.47 & 3.79 & 3.54 & 3.80 & 3.60 & 3.82 \\
\hline $5-10$ years & 3.44 & 3.71 & 3.43 & 3.68 & 3.49 & 3.77 \\
\hline $11-15$ years & 3.25 & 3.61 & 3.44 & 3.64 & 3.44 & 3.62 \\
\hline More than 15 years & 3.33 & 3.70 & 3.47 & 3.73 & 3.35 & 3.65 \\
\hline
\end{tabular}

Table 3 shows the average rate of total job satisfaction and employee benefit determinants for all three surveys based on the respondent's selected characteristics. Men, aged 30 to 40 as well as overall, that have been employed in the organisation for less than 5 years are more satisfied with employee benefits.

The results of 2017 again confirm the fact that overall job satisfaction in the Czech Republic has been at a very low level for a long time, as shown by previously published studies $[3 ; 4 ; 5 ; 7]$. 


\section{Conclusion and Recommendations}

Provision of employee benefits is dealt by a personnel policy that is an effective tool for personnel management that helps attract and retain high-quality employees to increase their loyalty to the employer, motivation and productivity, turnover reduction and the associated costs [1].

It's no longer true that employees are only motivated by wages. Business benefits can be a tool for recruiting new employees, companies can also make extensive use of their loyalty and motivation for their existing employees. On the other hand, future staff may be an important factor in deciding between several job offers.

In fact even in this difficult situation in the labour market, results show that companies don't use this option, since the cost of employee benefits decline slightly.

Companies must realise that currently they can't manage without a thoughtful motivation system for their own employees. Offered employee benefits help increase loyalty and employee satisfaction, or attract new employees.

Benefits are sometimes referred to as part of total remuneration. Creating and enhancing motivation is a long-term issue requiring a systematic approach with a good knowledge especially of psychology and sociology of work. By providing benefits, the employer can vary from competitor to gain a competitive advantage and strengthen the corporate culture - protecting and building up good reputation and enhancing the value of brand. Providing benefits also means increasing the image and attractiveness of the employer.

The reason why companies should use benefits for rewarding their employees (in addition to complying with the requirements of the law) is that employee benefits can:

- improve the company's reputation and competitiveness in the labour market and therefore facilitating the recruitment and stabilisation of employees;

- reduce employee dissatisfaction and fluctuation;

- promote the relaxation, development and social background of employees and therefore also their performance indirectly;

- improve employee relations, promote loyalty and identity with organisation or pride on employers.

Acknowledgements. The paper was written with the support of the specific project 6/2017 grant "Determinants affecting job satisfaction" granted by the University of Hradec Králové, Czech Republic and thanks to help of student Eliška Čonková.

\section{References}

1. Armstrong, M.: Ǩ́zení lidských zdrojů. [Human Resource Management.] 2nd. ed. Praha : Grada Publishing, 856 p. (2002).

2. Czech Statistical Office - ČZSO. Available at: https://www.czso.cz/. Last accessed 2017/10/10, (2016). 
3. Franěk, M., Večeřa, J.: Personal characteristics and job satisfaction, E+ M Ekonomie a management, Vol. 11, No. 4, pp. 63-76, (2008).

4. Franěk, M., Mohelská, H., Zubr, V., Bachmann, P., Sokolová,: M. Organizational and sociodemographic dete2rminants of job satisfaction in the Czech Republic, SAGE Open (2014) 4: DOI: 10.1177/2158244014552426.

5. Sokolová. M,, Mohelská. H., Zubr. V.: Pay and offer of benefits as significant determinants of job satisfaction - A CASE STUDY IN THE CZECH REPUBLIC, E+ M Ekonomie a management, Vol. 19, No. 1, pp. 108-120, (2016).

6. Spector, P. E.: Job satisfaction: Application, assessment, causes, and consequences. Sage, Thousand Oaks, (1997).

7. Večerník, J.: Skating on thin ice: A comparison of work values and job satisfaction in CEE and EU countries, International Journal of Comparative Sociology, Vol. 44, No.5, pp. 444-471, (2003). 